\title{
Review
}

\section{The Concept of Prodromal Parkinson's Disease}

\author{
Philipp Mahlknecht ${ }^{\mathrm{a}, \mathrm{b}}$, Klaus Seppi ${ }^{\mathrm{a}}$ and Werner Poewe ${ }^{\mathrm{a}, *}$ \\ ${ }^{a}$ Department of Neurology, Medical University Innsbruck, Austria \\ ${ }^{\mathrm{b}}$ Sobell Department of Motor Neuroscience, UCL Institute of Neurology, London, UK
}

\begin{abstract}
Parkinson's disease (PD) is currently clinically defined by a set of cardinal motor features centred on the presence of bradykinesia and at least one additional motor symptom out of tremor, rigidity or postural instability. However, converging evidence from clinical, neuropathological, and imaging research suggests initiation of PD-specific pathology prior to appearance of these classical motor signs. This latent phase of neurodegeneration in PD is of particular relevance in relation to the development of disease-modifying or neuroprotective therapies which would require intervention at the earliest stages of disease. A key challenge in PD research, therefore, is to identify and validate markers for the preclinical and prodromal stages of the illness. Currently, several nonmotor symptoms have been associated with an increased risk to develop PD in otherwise healthy individuals and ongoing research is aimed at validating a variety of candidate PD biomarkers based on imaging, genetic, proteomic, or metabolomic signatures, supplemented by work on tissue markers accessible to minimally invasive biopsies. In fact, the recently defined MDS research criteria for prodromal PD have included combinations of risk and prodromal markers allowing to define target populations of future disease modification trials.
\end{abstract}

Keywords: Parkinson's disease (PD), biomarker, early diagnosis, premotor PD, nonmotor symptoms (NMS), neuroimaging, genetic and molecular biomarkers

\section{INTRODUCTION}

Currently, the diagnosis of Parkinson's disease (PD) is anchored on clinical criteria, which require the presence of bradykinesia and at least one further motor symptom out of tremor, rigidity or postural instability [1] and pathological studies have shown a strong correlation between the extent of Lewy Body related cell loss in the Substantia Nigra (SN) and the severity of bradykinesia [2]. However, this clinico-pathological concept of PD is challenged by several lines of evidence: Firstly, it has been noted for more than 20 years that nigral cell loss and striatal dopamine depletion progress to an approximate threshold of at least $40 \%$

\footnotetext{
*Correspondence to: O. Univ.-Prof. Werner Poewe, MD, Department of Neurology, Innsbruck Medical University, Anichstraße 35, 6020 Innsbruck, Austria. Tel.: +43 512504 23850; Fax: +43 512 504 23852; E-mail: werner.poewe@i-med.ac.at.
}

before the first appearance of clinically defining motor signs [2,3]. Secondly, Braak and colleagues have proposed a staging scheme of PD pathology with initiation of $\alpha$-synuclein pathology in the caudal brainstem and the olfactory bulb and subsequent spread to the midbrain and eventually the limbic and neocortex [4]. This hypothesis has been extended by multiple studies suggesting early involvement of the peripheral autonomic nervous system in PD [5, 6]. Thirdly, the hypothesis of extra-nigral or even peripheral onset of disease seems to converge with clinical studies showing that PD patients may experience a variety of nonmotor symptoms before the first appearance of classical motor signs [7-9]. Indeed, hyposmia, constipation, depression and idiopathic REM Sleep Behaviour Disorder (RBD) have been shown to go along with a significantly increased risk to develop PD in otherwise healthy subjects in population-based or other cohort studies [10-17]. Taken together, these findings clearly 
Table 1

Conceptual stages of Parkinson's disease

\begin{tabular}{|c|c|c|c|}
\hline Phases of PD & Clinical status & Pathology & Comments \\
\hline $\begin{array}{l}\text { Phase } 1- \\
\text { preclinical }\end{array}$ & $\begin{array}{l}\text { No clinical signs or } \\
\text { symptoms }\end{array}$ & $\begin{array}{l}\text { PD-specific pathology assumed } \\
\text { to be present }\end{array}$ & $\begin{array}{l}\text { Supported by biomarkers (genetic, } \\
\text { molecular, and/or imaging) }\end{array}$ \\
\hline $\begin{array}{l}\text { Phase } 2- \\
\text { prodromal }\end{array}$ & $\begin{array}{l}\text { Early nonmotor } \\
\text { symptoms } \pm \text { early subtle } \\
\text { motor symptoms }\end{array}$ & $\begin{array}{l}\text { Extranigral PD pathology } \\
\text { (Braak stages } 1 \text { and } \\
\text { 2) } \pm \text { nigral PD pathology } \\
(<40-60 \% \text { cell loss; Braak } \\
\text { Stage } 3)\end{array}$ & $\begin{array}{l}\text { Criteria yet to be defined based on } \\
\text { clinical motor and nonmotor } \\
\text { markers and nonclinical } \\
\text { biomarkers. Two levels of certainty } \\
\text { have been proposed [19]: Probable } \\
\text { prodromal PD (high likelihood, } \\
\text { e.g., }>80 \% \text {; sufficiently certain for } \\
\text { neuroprotective trials) and possible } \\
\text { prodromal PD (lower, but still } \\
\text { substantial likelihood, e.g., } \\
30 \%-80 \% \text { ) }\end{array}$ \\
\hline Phase 3 - motor & $\begin{array}{l}\text { Classical motor } \\
\text { manifestations are present }\end{array}$ & $\begin{array}{l}\text { Nigral PD pathology ( }>40-60 \% \\
\text { cell loss; Braak stages } 3 \text { to } 6 \text { ) }\end{array}$ & $\begin{array}{l}\text { Current clinical diagnostic criteria } \\
\text { based on motor syndrome are } \\
\text { met; } \pm \text { a variety on nonmotor } \\
\text { symptoms may be present due to } \\
\text { the extension of PD pathology }\end{array}$ \\
\hline
\end{tabular}

Modified from Stern et al. 2012 [18].

speak to the existence of a stage of PD where affected subjects may be asymptomatic ('preclinical PD') or where they may present with a variety of nonmotor symptoms and/or subtle motor signs that do not meet current diagnostic criteria ('prodromal PD') [18, 19] (Table 1). Taken by themselves, however, these prodromal features lack specificity and - with the possible exception of RBD - have poor predictive value for PD. The challenge is, therefore, to characterise and validate markers that would enhance specificity and positive predictivity for currently prediagnostic stages of the illness. Here we review the current evidence for potential markers of preclinical or prodromal PD including clinical motor and nonmotor symptoms, neuroimaging measures, genetic susceptibility factors as well as molecular and biopsy biomarkers.

\section{PREDIAGNOSTIC NIGROSTRIATAL DYSFUNCTION IN PD}

\section{Neuropathological evidence}

Neuronal loss in the $\mathrm{SN}$ pars compacta $(\mathrm{SNc})$ associated with Lewy Body pathology is the pathologic hallmark feature of sporadic PD [20]. The extent of nigrostriatal dopaminergic denervation has been shown to correlate with severity of classical motor features of $\mathrm{PD}$, in particular bradykinesia and rigidity $[2,21]$. Different from age-related physiological cell loss in the SNc estimated to be in the order of 4 to $5 \%$ per decade, attrition of SNc dopaminergic neurons in PD seems to follow an exponential curve with an estimated 45\% loss in the first decade of disease [3]. Pathological studies have shown 40-60\% threshold of cell loss in the SNc and 60-70\% striatal dopaminergic depletion before the appearance of motor symptoms meeting current PD criteria and extrapolation of the curves suggested a prediagnostic phase of progressive nigral cell loss of 5 years [2,3]. Interestingly, incidental Lewy bodies are found in brainstem nuclei in more than $10 \%$ of individuals free of PD above age 60 and several lines of evidence argue that they may indicate preclinical stages of PD pathology rather than a by-product of neuronal aging [22, 23]. Clinicopathological studies found reduced nigral cell counts to be associated with increasing signs of subtle motor impairment also in subjects without PD [22, 23]. Individuals with incidental Lewy bodies in the $\mathrm{SN}$ and locus coeruleus were found to have loss of neurons in these nuclei as well as loss of tyrosine hydroxylase-positive fibres both in the striatum and epicardial fat which was intermediate between PD and normal controls [24]. Incidental Lewy bodies are also associated with nonmotor signs typically found in PD such as hyposmia [25] or constipation [26], again arguing that their presence may represent a presymptomatic phase of PD.

\section{Nigrostriatal dysfunction in PET/SPECT}

Nigrostriatal dopaminergic denervation can be shown using radiotracers that label presynaptic dopaminergic markers such as the striatal dopamine transporters (DAT) as routinely achieved with singlephoton emission computed tomography (SPECT) or 
decarboxylase activity with ${ }^{18} \mathrm{~F}$-Dopa positron emission tomography (PET). DAT imaging is closely correlated with post mortem SN cell counts [27] as well as severity and duration of disease [28] and has therefore been considered not only as a surrogate marker for disease progression, but also as a risk marker for PD [29]. Also, ${ }^{18}$ F-Dopa PET studies in PD patients have shown faster rates of tracer-uptake decline in earlier versus later disease stages and, in accordance with the pathological post-mortem studies, extrapolation of these exponential curves have led to estimates of prediagnostic PD of approximately 6 years [30-32].

\section{Subtle motor impairment and risk for PD}

It has been argued that compensatory mechanisms may effectively counteract nigrostriatal dysfunction at the onset of cellular dysfunction and decline of striatal dopamine, thus delaying the appearance of overt parkinsonism for many years [33, 34]. Although slight motor abnormalities such as reduced arm swing, changes in walking patterns, stiffness, tremor, or bradykinesia may precede clinical PD, such signs, captured by routine clinical assessment for parkinsonism [35], often referred to as subtle motor impairment or mild parkinsonian signs, may be found in as many as $40 \%$ of the elderly population $[36,37]$. In several studies mild parkinsonian signs have been associated with both other PD risk markers as well as with an increased risk for incident PD itself $[16,37]$. These signs, however, are quite unspecific in the general population. This may be different when motor tests are applied to enriched cohorts with an apriori increased risk for PD. Prospective studies in subjects with idiopathic RBD have shown that in those who converted to clinically defined PD, impaired motor performance was detected 6-9 years before diagnosis using the Purdue Pegboard, alternate-t $\mathrm{p}$ and timed up-and-go test [38]. Similarly, a more recent study by the same group following 89 idiopathic RBD patients over ten years found a 3.9 fold risk to develop PD, dementia with Lewy-bodies (DLB) or multiple system atrophy (MSA) in those with subtle motor impairment at baseline [14]. Using accelerometry-based evaluation of gait and stance, two cross-sectional studies found altered gait variability [39], trunk acceleration and smoothness of sway [40] under challenging conditions in otherwise asymptomatic LRRK2 mutation carriers and subjects with hyperechogenicity of the SN. Noyce and colleagues used an algorithm based on an online survey to categorise participants according to their putative PD risk [41] in the definition of their prospective PREDICT-PD study cohort [42]. In a cross-sectional baseline analysis, the 100 highest-risk participants had significantly reduced tapping speed in a novel computer keyboard-tapping task versus the 100 lowest-risk participants [42]. Quantifiable motor tests may therefore eventually become useful as a screening element to select at-risk subjects for further secondary screens with more specific tests like DAT imaging.

\section{EARLY NONMOTOR SYMPTOMS AND THE CONCEPT OF PREMOTOR PD}

It is now well recognized that nonmotor symptoms are an integral part of the clinical spectrum of the disease [43-46] and may even antedate the clinical manifestation of cardinal motor features of PD by several years in a substantial proportion of patients [7-9, 47] (Table 2). Considering Braak's hypothesis that PD pathology first starts in extranigral sites, particularly the olfactory system, lower brainstem and peripheral autonomic nervous system [4, 5, 48], it is intriguing to note that recent clinical studies have found certain nonmotor symptoms such as constipation, dream enacting behaviour, and smell-loss preceding the onset of first motor complaints into time periods that are longer before motor onset as compared to other nonmotor complaints $[7,9]$.

\section{Hyposmia}

Olfactory detection, identification or discrimination deficits have consistently been found in approximately $80 \%$ of patients with PD [56, 57]. Although many patients retrospectively report smell loss prior to noting the first motor problems $[7,9]$, to date there are only two population based studies that have investigated prospective risk for PD in relation to baseline smell function [16, 17]. In the Honolulu-Asia Aging study (HAAS), a large cohort of more than 2000 men of Japanese ancestry was prospectively followed for PD incidence with respect to baseline olfactory performance using the Brief Smell Identification Test (B-SIT) [17]. After adjustment for age and other potential confounders, the odds ratio for incident PD within four years in those with the lowest quartile of B-SIT scores at baseline was 5.2 and 3.1 in the second lowest quartile as compared with the top two quartiles. However, hyposmia was not associated with PD risk beyond four years. Intriguingly, a clinicopathologic study in a subsample from the HAAS, found an association of olfactory dysfunction with incidental Lewy 


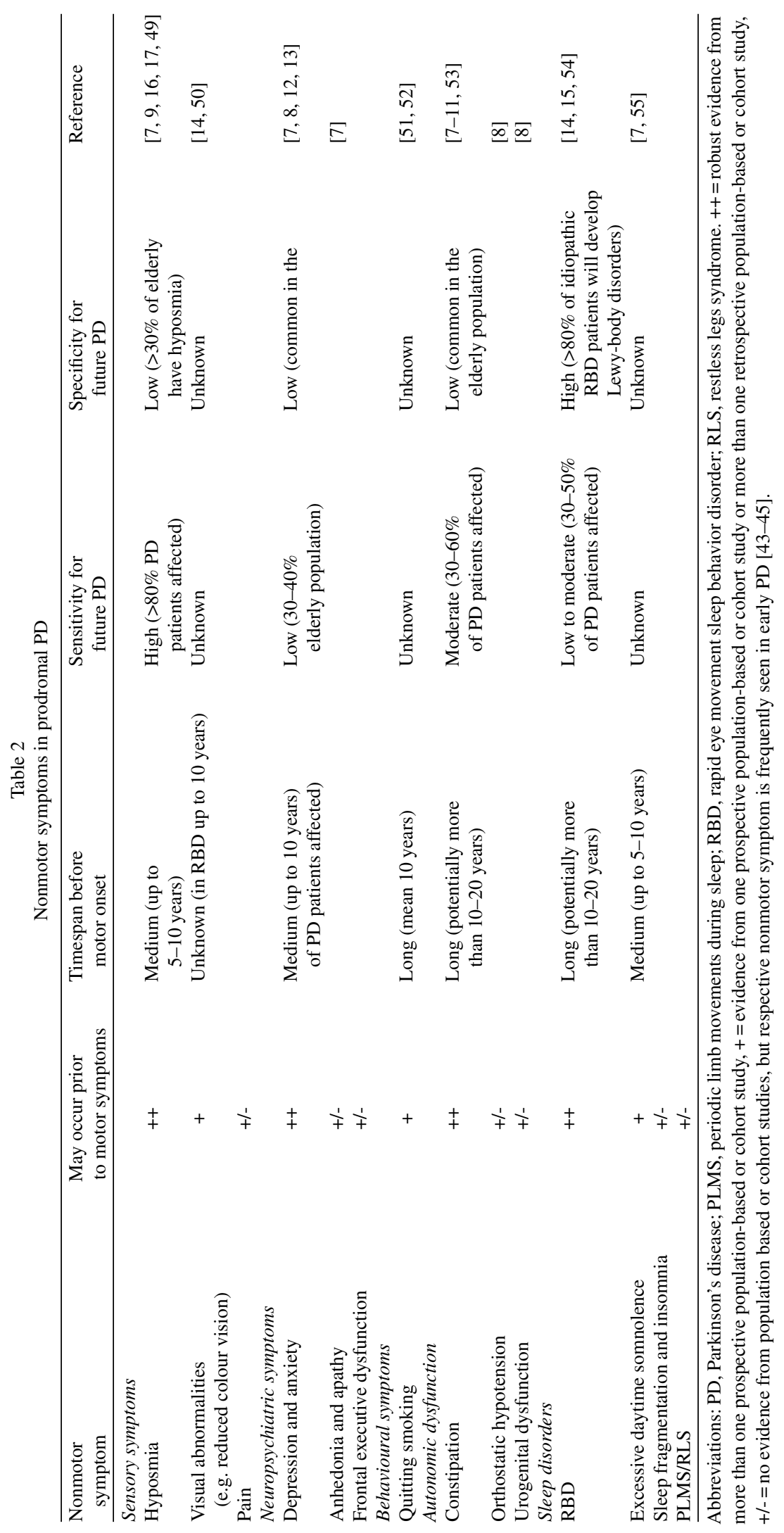


bodies in the SN [25]. Likewise, the PRIPS study, a large population-based cohort study on risk factors for incident PD (see imaging biomarkers), found a relative risk ratio of 6.5 in hyposmic participants over 3 years [16]. More recently, several studies have addressed the potential of hyposmia as a risk marker for PD in subjects with increased apriori risk for PD. For example, two recent prospective cohort studies of idiopathic RBD patients found that baseline olfactory dysfunction predicted incident Lewy body disorders over 5 and more years of follow-up [14, 58].

\section{REM-sleep behavior disorder (RBD)}

RBD is a parasomnia clinically characterized by dream-enacting behaviours related to loss of physiological atonia during REM-sleep [59]. The prevalence of idiopathic RBD in the population is not well defined as definite diagnosis requires polysomnography. A commonly cited figure of $0.4 \%$, however, may well be an underestimate [60]. Indeed, when using two validated screening questionnaires in an elderly populationbased sample of 476 subjects, we recently found a prevalence of probable RBD of 5-8\% in a Caucasian population aged $>60$ years [61]. In this particular cross sectional study, probable RBD was associated with multiple other nonmotor markers of PD, while polysomnography was not available. Idiopathic RBD is increasingly recognized as a harbinger of neurodegenerative diseases, including not only PD but also other synucleinopathies like DLB or MSA. Several follow-up studies have found that the majority of subjects with idiopathic RBD (>80\%) will convert into one of these disorders - most commonly PD or DLB - with extended follow-up over decades [15, 54, 62]. Two recent prospective cohort studies have further substantiated these observations. Postuma and colleagues collected follow-up data in a multicentre sample of 305 patients with idiopathic RBD over up to 6 years and found an overall conversion to neurodegenerative diseases of $33 \%$ [63], which was time-dependent at $15 \%$ after 2 years, $25 \%$ after 3 years, and $41 \%$ after 5 years. Conversion to PD or DLB was common ( $42 \%$ and $50 \%$, respectively), while only $8 \%$ converted to MSA. Idiopathic RBD patient who converted over the observational period were older, more likely to report a family history of dementia, and more frequently endorsed autonomic and/or motor symptoms on questionnaires compared to those who remained disease free, whereas many baseline characteristics including caffeine and nicotine exposure were not different between these groups [63]. With the aid of thorough testing batter- ies, conversion from RBD to PD or PD Dementia/DLB appears to be more predictable. One recent prospective study in 89 idiopathic RBD patients found that smell identification loss (hazard ratio (HR) 2.8), abnormal colour vision (HR, 3.1), and subtle motor impairment (HR, 3.9), as well as advanced age (HR, 1.1) and nonuse of anti-depressants (HR, 3.5) was associated with conversion to one of these synucleinopathies (including MSA) over the 7.5 year observational period.

Taken together, current evidence shows that RBD is the most specific among the different risk factors for PD (see Table 2) and RBD cohorts seem obvious candidates for future disease-prevention studies for PD. However, the median latency to conversion into clinically defined PD can be as long as 12 to 14 years $[15,54]$, seriously limiting the feasibility of such trials. Therefore, we recently investigated whether olfactory impairment can predict early conversion to $\mathrm{PD}$ or PDD/DLB among 35 idiopathic RBD patients prospectively followed over 5 years [58]. Indeed, abnormal baseline performance on the multidimensional Sniffin Sticks test assessing odour identification, odour discrimination, and olfactory threshold predicted conversion to a Lewy body disorder with an accuracy of $82.4 \%$, and this was also true for poor performance on the identification subscore only. Based on the findings from this cohort, sample sizes for a hypothetical neuroprotection trial in RBD with conversion to a Lewy body disorders as an endpoint could be reduced by 74-80\% for a 5-year trial if idiopathic RBD patients were pretested for baseline olfactory dysfunction. For example, a total of 760 patients with idiopathic RBD versus 188 patients with idiopathic RBD and olfactory dysfunction would be required to have an $80 \%$ chance to detect a $30 \%$ decrease in the primary outcome measure of conversion to a Lewy body disease [58]. Similar data were also reported by Postuma et al. who found that by excluding idiopathic RBD subjects $<55$ years of age or using antidepressants reduced estimated sample sizes for 3-year neuroprotection trials with the same outcome measure by $\geq 25 \%$ when further pretesting for olfactory dysfunction, impaired colour vision, or subtle motor impairment and by $\geq 40 \%$ when using combinations of these markers [14].

\section{Constipation}

Constipation is common in PD affecting 28-61\% of patients [46]. In the Honolulu-Asia Aging study men with bowel movement frequencies of less than once per day had a relative risk for incident PD of at least 2.7 compared to men with more frequent bowel 
function [10]. The brains of 245 subjects from this cohort were available for post-mortem examination and - consistent with the above finding - there was a significant association of constipation in life with the prevalence of incidental Lewy Bodies in the SN at post-mortem: $24.1 \%$ of those who had reported less than 1 bowel movement per day had this pathologic feature as compared to $6.5 \%$ of those with bowel movement frequencies of greater than 1 per day [65]. Interestingly, several studies have recently reported on findings of synuclein-immunostaining in the enteric nervous system of PD subjects using colonic biopsies providing a possible link between colonic dysmotility and synuclein-related neurodegeneration in PD $[65,66]$. However, specificity for PD seems to be rather low (see below under tissue biomarkers).

Intriguing as these associations are, none of the nonmotor symptoms discussed above in themselves have sufficient specificity to qualify for screening for PD risk in the population. While sensitivity for future PD can be as high as $80 \%$ for features like hyposmia or constipation, their specificity is low [47]. Although specificity and predictive value of idiopathic RBD for PD risk are much higher, sensitivity is quite low. In addition, for low prevalence disorders like PD, by definition positive predictive values of any of the features discussed are small and would only be in the order of 50\% even for markers of $99 \%$ specificity [67]. Therefore, future screening tools to narrow down atrisk populations for PD will likely require the use of multiple markers potentially including imaging and molecular biomarkers.

\section{BIOMARKERS FOR PD}

A biomarker is a characteristic that is objectively measured and evaluated as an indicator of normal biological processes, pathogenic processes, or pharmacologic responses to a therapeutic intervention [68]. Several candidate PD biomarkers have emerged over the years and some are already established as useful diagnostic markers, particularly those related to neuroimaging. There is also exciting progress in the field of genetic and other molecular markers and recently also of tissue markers that can be accessed through biopsies.

\section{Imaging biomarkers}

\section{Radiotracer imaging}

Among various imaging techniques, radiotracerbased functional imaging currently offers the highest degree of accuracy in the diagnostic work-up of patients with early PD [29]. Decreased nigrostriatal dopaminergic function is associated with nonmotor symptoms known to precede PD. In a prospective study of first-degree relatives of PD patients, individuals with an olfactory dysfunction showed a faster decline of DAT binding compared to individuals with normal olfactory function [69]. Moreover, 10\% of hyposmic individuals, who also had abnormal DAT binding at baseline, developed PD at 2 years and this figure rose to $12.5 \%$ at 5 years of follow-up [49]. Another recent prospective study showed that idiopathic RBD patients exhibited decreased DAT binding and faster rates of DAT-binding decline compared to healthy controls [70]. After 3 years of follow-up, 15\% of RBD patients, who also had the lowest DAT binding at baseline, had developed PD. As DAT imaging is invasive, time consuming, and expensive, it would not lend itself for primary screening purposes but rather as a secondary screen in enriched populations, such as those with nonmotor symptoms. A recent report on sequential biomarker assessment of population-based hyposmia screening in a first and DAT imaging in a second step - the Parkinson At-Risk Syndrome (PARS) study reported decreased radiotracer binding using DATSPECT to be present in $11 \%$ of hyposmic compared with $1 \%$ of normosmic participants [71]. Also male sex and constipation were predictive for a DAT-deficit such that combining these three factors increased the percentage of subjects with a DAT deficit to $40 \%$ [71]. In contrast to DAT imaging assessing nigrostriatal function, which is an established imaging method in neurodegenerative parkinsonism, direct visualisation of the neuropathologic process i.e. $\alpha$-synuclein deposition and related neurodegeneration is not yet possible. In analogy to the Pittsburgh compound-B, an in vivo $\mathrm{A} \beta$ ligand labeling amyloid depositions in Alzheimer's dementia, PET radiotracers specific for $\alpha$-synuclein are beeing developed [72]. Longitudinal imaging of $\alpha$-synuclein could particularly be relevant in the context of clinical neuroprotection-trials and serve as a surrogat outcome.

\section{Magnetic resonance imaging}

There is limited information as to the potential of magnetic resonance imaging (MRI) to detect brain changes associated with PD risk or prodromal PD. Two studies in patients with idiopathic RBD found alterations in diffusivity measures in the tegmentum of the midbrain and the pontine reticular formation, regions involved in the generation of REM sleep [73, 74]. In a functional MRI study, asymptomatic subjects with 
a heterozygous Parkin and PINK1 mutation exhibited additional recruitment of supplementary motor areas as an expression of compensatory mechanisms [34]. In early PD significant alterations in various MRI diffusivity measures in the SN $[75,76]$, olfactory tract $[75,77]$ and cortex [78] were found compared with healthy controls at a field strength of $1.5 \mathrm{~T}$ and at a higher field strength of 3.0 T. Two studies reported a complete separation of early PD patients from controls using fractional anisotropy values in the caudal $\mathrm{SN}$ at $3.0 \mathrm{~T} \mathrm{[76]} \mathrm{and} \mathrm{in} \mathrm{the} \mathrm{olfactory} \mathrm{tract} \mathrm{at} 1.5 \mathrm{~T}$ [75].

Using T2*-weighted 7T MRI, a recent study described a hyperintense ovoid area within the dorsolateral border of the otherwise hypointense SN pars compacta consistent with nigrosome 1 in healthy controls [79]. The absence of this feature was highly sensitive and specific for PD. Intriguingly, the presence of this feature assessed with susceptibility weighted imaging (SWI) at 3T distinguished PD patients from healthy controls in another dataset of the same group [80] as well as in our own large cohort of patients with neurodegenerative parkinsonism [81], with a sensitivity and specificity of $>90 \%$, respectively (Fig. 1). In the latter study also all included patients with MSA and PSP exhibited this imaging feature (i.e. sensitivity of $100 \%$ ), indicating that visual assessment of dorsolateral nigral hyperintensity on high-field SWI scans may serve as a new simple diagnostic imaging marker for neurodegenerative parkinsonian disorders [81]. Future studies will have to elucidate whether these or other changes in MRI measures can be visualized in subjects exhibiting other PD risk markers and serve as biomarkers for the premotor stage of the illness.

\section{Transcranial sonography}

Over the past 2 decades, there has been considerable interest in the use of transcranial sonography (TCS) in $\mathrm{PD}$ - a method which is less expensive, time consuming and more widely available compared to radiotracer or MR imaging [82]. An enlarged echogenic area at the anatomical site of the $\mathrm{SN}$ in the mesencephalic scanning plane, termed SN-hyperechogenicity, has consistently been found in at least $82 \%$ of PD cases but only in up to $23 \%$ of healthy controls [82, 83] (Fig. 1). In PD patients, the SN-echogenic sign is neither related to disease severity nor does it change over time $[82,84]$ and its longitudinal stability has also been reported in healty controls [85] and idiopathic RBD patients [86]. Although the pathophysiologic underpinnings of this echo feature are not entirely clear, histopathological studies have shown a relation of $\mathrm{SN}$ echogenicity with an increased SN iron and ferritin content [87] as well as with decreased neuromelanin and microglial activation in the SN in healthy subjects [88]. Functional imaging studies demonstrated its association with a decreased ${ }^{18} \mathrm{~F}$-Dopa uptake in healthy controls and SN-hyperechogenicity may therefore represent a surrogate marker of an increased

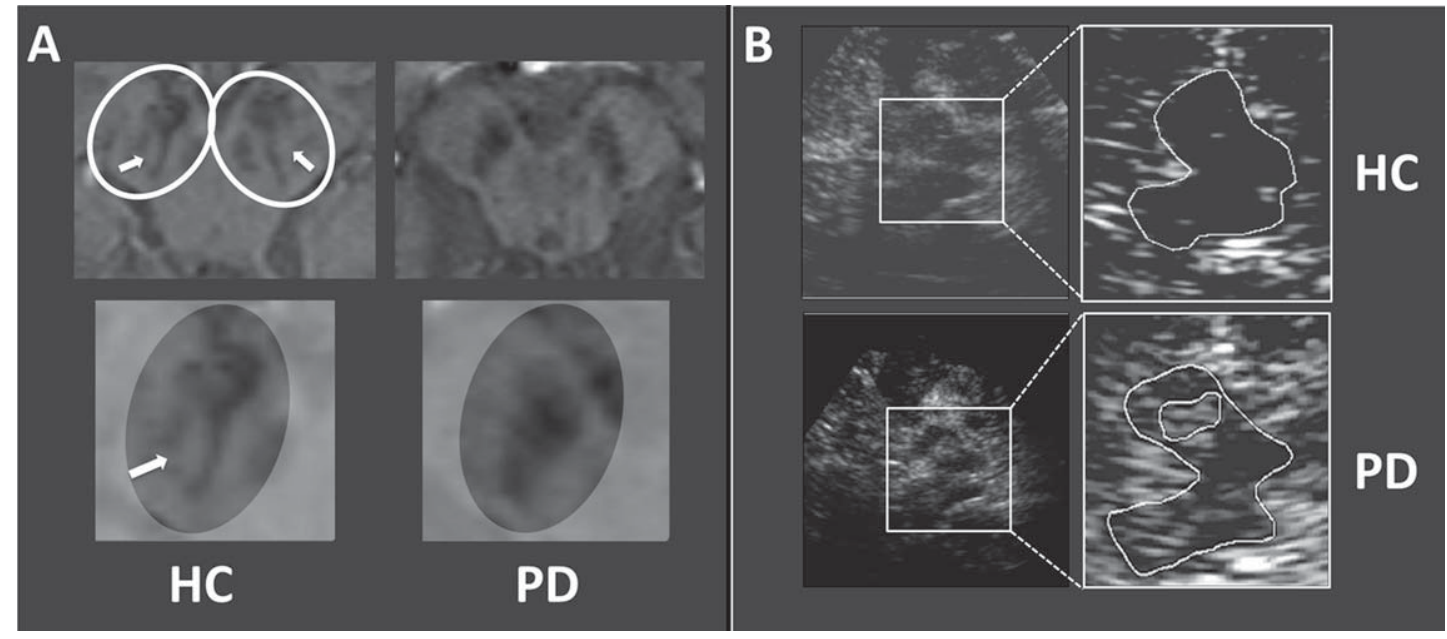

Fig. 1. Midbrain/substantia nigra (SN) imaging with magnetic resonance imaging (MRI) and Transcranial sonography (TCS). A: Susceptibility weighted (SWI) MRI image of a healthy control (HC) at the left column, demonstrating the magnified dorsolateral nigral hyperintensity within the right SN. White arrows mark the dorsolateral nigral hyperintensity in the survey as well as in the magnified illustration. The right column show SWI images of a patient with Parkinson's disease (PD), demonstrating the absence of the dorsolateral nigral hyperintensity. B: TCS images of mesencaphalic scanning planes showing typically butterfly-shaped mesencephalic brainstems from a HC with a normal midbrain echogenicity in the upper images. A PD patient with an enlarged midbrain echogenicity at the area of the SN (SN-hyperechogenicity) is shown in the lower images. 
vulnerability of the nigrostriatal dopaminergic system $[87,89,90]$. Whether SN-hyperechogenicity is suitable as a preclinical risk marker for PD in healthy elderly populations has recently been investigated in the PRIPS (Prospective validation of risk markers for the development of parkinsonian syndromes) study, a large population-based cohort study with promising results. Data from the 3- and 5-year follow-up investigations revealed a 17 - and 21 -fold increased risk of developing clinically defined PD in subjects exhibiting SN-hyperechogenicity compared to those without this echo-signal [16,91,92]. Interestingly, in a subset of this cohort, SN-hyperechogenity has even been shown to increase the risk for incident mild parkisonian signs over 5 years by about 2 -fold, which increased to a 3-fold risk when combined with hyposmia [93].

By combining the imaging modalities ${ }^{18} \mathrm{~F}$-Dopa PET, MRI, and TCS, one study found that putaminal ${ }^{18} \mathrm{~F}$-Dopa uptake and $\mathrm{T} 2$ relaxation times of the $\mathrm{SN}$ in control subjects with SN-hyperechogenicity were between the values of PD patients and controls without SN-hyperechogenicity [90]. A recent study assessed a set of biomarkers including SN-echognicity in symptomatic and asymptomatic LRRK2 G2019S mutation carriers as well as in patients with sporadic PD and healthy controls [94]. SN-hyperechogenicity was observed not only in approximately $95 \%$ of sporadic and genetic PD cases but also in $85 \%$ of asymptomatic LRRK2 G2019S mutation carriers as compared to $15 \%$ of healthy controls [94], further substantiating the concept of SN-hyperechogenicity as vulnerability marker of the nigrostriatal dopaminergic system.

\section{Genetic biomarkers}

The diagnosis of idiopathic PD has become more complex thought the discovery of Mendelian genes which cause monogenic forms of the disease such as autosomal dominant mutations in the SNCA, LRRK2 or VPS35 genes and autosomal recessive Parkin or PINK1 mutations. Taken together these account for a small percentage of PD cases seen in clinical practice, but asymptomatic carriers of dominant PD mutations like LRRK2 are obvious candidates when trying to study the preclinical phase of PD. In addition, several other genes have been identified which contribute to an increased risk for the sporadic form of the disease [95]. Derived from careful clinical observations of parkinsonism in patients with Gaucher's disease and their relatives, heterozygous mutation in the glucocerebrosidase (GBA) gene has been found to associate with
PD risk with an odds ratio of 5.4 [96]. Penetrance of this mutation seems to be high [97] and the prevalence of GBA mutations in PD populations has been between 3 and $20 \%$ in different studies, with the highest rates found in PD patients of Ashkenazi Jewish ancestry [96-99]. Importantly, pathogenic GBA variants are found in 1-3\% of the population [96] and are associated with deterioration in clinical markers of PD consistent with prodromal PD [99]. A more recent discovery is the association of mutations in the GTP cyclohydrolase 1 gene, representing the most common cause of DOPA-responsive dystonia, with sporadic PD with an odds ratio of 7.5 [100]. Pathogenic variants of this gene, however, seem to be rather rare in the population. Many more common low-risk susceptibility variants in other loci have only recently been identified and confirmed in large meta-analysis of datasets from genome-wide association studies (GWAS) in PD (Table 3). Although the effects of single genetic susceptibility factors seem to be small with odds ratios for each locus ranging from 0.7 to 1.8 , risk profile analysis showed substantial cumulative risk in a comparison of the highest and lowest quintiles of genetic risk with odds ratio of 2.5 (95\% CI 2.2-2.8) in one [101] and 3.3 (95\% CI 2.6-4.3) in a more recent study [102] (Table 3). Many of the reported genes such as SNCA and LRRK2 are also known to encode for key-player proteins in PD pathogenesis [95]. A dedicated online database has recently been created, where results of all published genetic association studies in PD and metaanalysis are freely available (http://www.pdgene.org) [103]. In addition, a polygenic risk score, consisting of small effect allels, has recently been identified in a discovery GWAS dataset and replicated in 3 independent GWAS datasets [104]. The average polygenic score in patients with an early disease age at onset was significantly higher than in those with a late age at onset [104], substantiating the hypothesis that accumulation of common polygenic alleles with relatively low effect sizes may considerably enhance overall PD risk and anticipate disease onset.

However, the true value of genetic risk scores (GRS) in the prediction of incident 'sporadic' PD is currently unknown. A recent study combined a GRS from 30 genetic risk factors with other PD markers using stepwise logistic regression analysis to identify PD cases in the Parkinson Progression Marker Initiative (PPMI) cohort as a training dataset [105]. The final model included GRS, olfactory function, family history of $\mathrm{PD}$, age, and sex and was associated with an excellent separation of PD cases from controls in 5 independent validation cohorts (AUCs >0.92) [105]. When looking 
at the single markers however, olfactory assessment was most responsible for the explained variance $(63 \%)$, followed by the GRS (14\%), family history (11\%), sex $(6 \%)$, and age $(6 \%)$ underlining the importance of olfactory testing for clinical and research purposes. Future prospective studies will have to assess the true value of this or similar models for the identification of prodromal PD.

\section{Molecular biomarkers}

In addition to the recent genomic discoveries, proteomic markers mostly assessed in the cerebrospinal fluid (CSF) are also subject of great research interest [107]. Alpha-synuclein-related parameters were investigated in CSF of PD patients and control populations, in some studies also in combination with DJ1 (Table 4). Results have been inconsistent, which may be due to various confounders, different methodologies used for specimen collection and analysis and due to a lack of standardized operating procedures [108]. The latter will change with prospective multicentre studies such as PPMI, where 400 newly diagnosed PD patients and 200 healthy controls are undergoing regular CSF and imaging marker assessments in an attempt to identify diagnostic and progression biomarkers [109], as well as premotor and genetic markers in recently added substudies. First results in a cross sectional analysis of a subset of the cohort showed lower levels of $A \beta 1-42$, T-tau, P-tau181, $\alpha$-synuclein, and T-tau/A $\beta_{1-42}$ early drug naive $\mathrm{PD}$ patients compared with healthy controls with a marked overlap between groups [110]. Also, recent meta-analyses of total a-synuclein in the CSF have found decreased levels compared to healthy controls with, however, substantial overlap resulting in a suboptimal diagnostic accuracy with a good sensitivity of $88 \%$ but a poor specificity of $40 \%$ for PD $[111,112]$. Evaluation of a-synuclein and DJ1 in the plasma has produced conflicting results and may be futile as erythrocytes are the greatest source of these proteins in the blood and the slightest degree of hemolysis considerably influences measurements [113]. Other proteins in the peripheral biofluids have been investigated: Using an unbiased proteomic screening approach, a recent study found 11 plasma proteins to be associated with age at PD onset [114]. Among those, low levels of apolipoprotein A1 (ApoA1), the main component of high density lipoproteins (HDL), correlated with earlier PD onset also in a replication cohort and were furthermore associated with greater putaminal DAT deficit among hyposmic subjects at risk for PD in the PARS cohort [114]. These results have been replicated by the same authors in other cohorts including a subset of the PPMI study, where the same direct association with age at disease onset has been found for HDL levels [115]. ApoA1/HDL would represent a particularly interesting PD risk marker, as it is potentially modifiable by drugs like statins. The latter study did, however, not adjust for cofounders of ApoA1/HDL levels such as statin use [115]. Moreover, studies on the influence of statins on PD risk have been conflicting with some showing a decreased risk [116] and others an increased risk for the disease among statin users [117], the latter being in line with evidence of high total cholesterol and/or low density lipoprotein as a protective factor against PD [118, 119]. Therefore, more experimental and longitudinal clinical and population-based studies, thoroughly adjusting for multiple confounders, are warranted before ApoA1/HDL elevating drugs may be tested in prospective clinical neuroprotection trials.

Although there are other recent promising advances in molecular biomarker research including the measurement of microRNAs in blood of PD and RBD patients significantly differing from healthy controls $[120,121]$, there is currently no molecular marker or combination of markers that could reliably show increased risk to develop PD. However, in Alzheimer's disease, which has a pioneering role in neurodegenerative disease research, such biomarkers have been developed and incorporated in diagnostic guidelines [122]. Given the rapidly advancing biochemical technologies, it is strongly hoped that a premotor biochemical biomarkers can be discovered in PD-risk populations [123].

\section{Tissue biomarkers}

The exact clinocopathological correlations underlying the various NMS in PD or pre-PD are still poorly defined. Orthostatic hypotension and constipation may well be mediated by cardio-sympathetic and vasomotor denervation as well as pathology in the enteric nervous system, respectively. Indeed, recent studies have provided consistent evidence for synuclein-related pathology in the peripheral autonomic nervous system using skin punch biopsies, biopsies of the salivary glands as well as colonic biopsies [131-136]. Biopsy studies of synuclein immunostaing in colonic mucosa and submucosa in PD have produced inconsistent results with some authors reporting differences in the percentage of immunopositive samples in PD versus controls [66, 137, 138] and others finding no difference in the prevalence 
Table 3

Parkinson's disease risk genes - evidence from genome genome-wide association studies

\begin{tabular}{|c|c|c|c|}
\hline Study & Design & Subjects & Results \\
\hline Nalls et al. 2011 [101] & $\begin{array}{l}\text { Meta-analysis from } 5 \text { GWAS } \\
\text { (USA \& Europe) }\end{array}$ & $\begin{array}{l}\text { Discovery set: } 5,333 \text { PD and } \\
12,019 \text { controls; } \\
\text { Replication set: } 7,053 \text { PD } \\
\text { and 9,007 controls }\end{array}$ & $\begin{array}{l}\text { - Previously identified loci } \\
\text { confirmed: MAPT, SNCA, } \\
\text { HLA-DRB5, BST1, GAK } \\
\text { and LRRK2 } \\
\text { - Newly identified loci: } \\
\text { ACMSD, STK39, } \\
\text { MCCC1/LAMP3, SYT11, } \\
\text { and CCDC62/HIP1R } \\
\text { - Odds ratio of } 2.5 \text { (95\%CI } \\
\text { 2.2-2.8) in the highest } \\
\text { versus the lowest quintile } \\
\text { of disease risk }\end{array}$ \\
\hline Pankratz et al. 2012 [106] & $\begin{array}{l}\text { Meta-analysis from } 5 \text { GWAS } \\
\text { (USA) }\end{array}$ & $\begin{array}{l}\text { Discovery set: } 4,238 \text { PD and } \\
4,239 \text { controls; Replication } \\
\text { set: } 3,738 \text { PD and } 2,111 \\
\text { controls }\end{array}$ & $\begin{array}{l}\text { - Association with SNCA, } \\
\text { MAPT, GAK/DGKQ, GBA } \\
\text { and the HLA region } \\
\text { confirmed } \\
\text { - Novel locus RIT2 }\end{array}$ \\
\hline Lill et al. 2012 [103] & $\begin{array}{l}\text { Meta-analysis from GWAS } \\
\text { and PD association studies } \\
\text { (literature screen) }\end{array}$ & $\begin{array}{l}\text { Up to } 16,452 \text { PD and } 48,810 \\
\text { controls (from } 828 \text { studies) }\end{array}$ & $\begin{array}{l}\text { - Association with BST1, } \\
\text { CCDC62/HIP1R, } \\
\text { DGKQ/GAK, GBA, } \\
\text { LRRK2, MAPT, } \\
\text { MCCC1/LAMP3, } \\
\text { PARK16, SNCA, STK39, } \\
\text { and SYT11/RAB25 } \\
\text { - Novel locus ITGA8 } \\
\text { - Results freely available on: } \\
\text { www.PDGene.org }\end{array}$ \\
\hline Nalls et al. 2014 [102] & $\begin{array}{l}\text { Meta-analysis from multiple } \\
\text { GWAS in USA and Eurpoe }\end{array}$ & $\begin{array}{l}\text { Discovery set: } 13,708 \text { cases } \\
\text { and } 95,282 \text { controls; } \\
\text { Replication set: } 5,353 \text { cases } \\
\text { and } 5,551 \text { controls }\end{array}$ & $\begin{array}{l}\text { - Of the } 32 \text { SNPs tested in the } \\
\text { replication set ( } 26 \text { loci } \\
\text { identified in the discovery } \\
\text { phase and } 6 \text { previously } \\
\text { reported loci) } 24 \text { were } \\
\text { replicated including } 6 \\
\text { newly identified loci } \\
\text { - } 4 \text { loci (GBA, GAK/DGKQ, } \\
\text { SNCA and the HLA region) } \\
\text { contained a secondary } \\
\text { independent risk variant } \\
\text { - Odds ratio of } 3.3 \text { (95\%CI } \\
\text { 2.6-4.3) in the highest } \\
\text { versus the lowest quintile } \\
\text { of disease risk }\end{array}$ \\
\hline
\end{tabular}

Table 4

Selection of studies assessing the potential of a-synuclein- and DJ1-based CSF markers for detecting PD

\begin{tabular}{|c|c|c|c|c|c|}
\hline $\begin{array}{l}\text { Marker/Study } \\
(\mathrm{REF})\end{array}$ & $\begin{array}{c}\text { Change } \\
\text { in PD }\end{array}$ & Sensitivity & Specificity & Comments & References \\
\hline \multirow[t]{2}{*}{ Total $\alpha$-Syn } & $\downarrow$ & $71 \%-100 \%$ & $38 \%-58 \%$ & & {$[110,124-128]$} \\
\hline & $\downarrow$ & $91 \%$ & $25 \%$ & Studies in early drug-naive PD & {$[110,128]$} \\
\hline Phosphorylated & $\uparrow$ & $61 \%$ & $80 \%$ & For combined phosphorylated and total & [129] \\
\hline$\alpha$-Syn & & $80 \%$ & $64 \%$ & $\alpha$-Syn using two different cut-off values & \\
\hline$\alpha$-Syn & $\uparrow$ & $75 \%$ & $88 \%$ & $\alpha$-Syn oligomers alone & {$[130]$} \\
\hline Oligomers & & $89 \%$ & $91 \%$ & Ratio to total $\alpha-S y n$ & \\
\hline DJ1 & $\downarrow$ & $90 \%-97 \%$ & $50 \%-70 \%$ & & {$[124,125]$} \\
\hline
\end{tabular}

of synuclein-immunostaining of the enteric nervous system [139]. Differences between studies might be related to differences in tissue preparation, staining techniques and antibodies used [136]. For example a recent study only found possible differences between PD and controls when using antibodies against phosphorylated $\alpha$-synuclein [140], but this has again not been the case in another report [139]. In addition, 
synuclein immunopositivity may depend on the site of specimen collection with higher densities in the rostral as compared to caudal aspects of the gut [136]. A recent study found $\alpha$-synuclein pathology also in the gastric mucosa of PD patients with a sensitivity of $85 \%$ and a specificity of $95 \%$ [141]. Interestingly, $\alpha$-synuclein pathology was identified in some PD patients, in whom gut biopsies were taken up to 8 years prior to a clinical diagnosis of PD [142, 143] and one study has found positive immunostaining for phosphosynuclein in some individuals with RBD but in none of a group of age-matched controls [140]. The specificity of such findings for preclinical or prodromal PD still needs to be defined as there are studies strongly suggesting that $\alpha$-synuclein is a normal constituent of nerve fibres and ganglionic cells in the enteric nervous system [136, 144]. Two studies have recently reported increased aggregation of phospho-synuclein and fibre loss in autonomic sudomotor and pilomotor fibres in skin punch biopsies in PD patients but not in healthy controls $[132,133]$. Another region of potential specimen collection for the detection of peripheral $\alpha$-synuclein may include the salivary glands; although biopsies of minor salivary glands largely lack $\alpha$-synuclein depositis [134, 145], pre- and postmortem studies using submandibular gland tissue have found phosphorylated $\alpha$-synuclein in most PD cases [134]. While olfactory bulb $\alpha$-synuclein is highly specific and sensitive for Lewy body disorders [146], a study using peripheral olfactory epithelium failed to detect $\alpha$-synuclein [147]. Out of all $\alpha$-synuclein related biopsy markers, specimen from the gastronintestinal tract and the salivary glands appear to be the most promising candidate tissue for detection of PD specific pathology [136].

Related to the findings of PD specific pathology in the gut, it seems important to mention that an altered gut microbiom has recently been identified by two studies in PD patients as compared to controls [148, 149]. A proinflammatory effect of the altered microbiosis has been suggested to trigger enteric synuclein-aggregation and subsequent spread of PD pathology $[149,150]$. Further studies will have to look into potential relations and pathophysiological relevance of the microbiome in PD as well as its role for PD risk prediction.

\section{OUTLOOK}

There is now converging and compelling evidence for the existence of a latent phase of PD where disease specific molecular events of intracellular $\alpha$-synuclein misfolding, oligomer and fibril formation are initi- ated to eventually cause neuronal dysfunction and cell death. For unknown periods of time this process may remain clinically asymptomatic ('Preclinical PD') or may cause motor or nonmotor symptoms that are in themselves unspecific and do not meet current diagnostic criteria for PD ('Prodromal 'PD). Recent experimental data strongly suggest that the evolution and clinical progression of PD may be largely driven by cell-to-cell propagation of pathogenic $\alpha$-synuclein species in the central and also peripheral autonomic nervous system in a prion-like fashion [151, 152]. Therapeutic interventions should therefore ideally target the triggering pathogenic events as early as possible to achieve not only slowing of disease progression but also forestalling of disease onset. This makes early diagnosis a key priority and creates an urgent need for valid PD biomarkers with predictive validity for PD diagnosis. Until now several nonmotor clinical features have been shown to associate with PD risk and the combined occurrence of RBD and hyposmia in otherwise asymptomatic subjects has been shown to associate with the development of clinically defined PD or other Lewy body disorders in a substantial proportion over a relatively short time. While this makes RBD patients a realistic target population for future disease prevention studies of PD, it falls short of defining PD risk at the population level. Combinations of demographic, clinical, genetic and imaging markers have now been tested in large PD samples and also at the population level with promising results regarding diagnostic accuracy as well as definitions of PD risk. Searching for synuclein deposition in nervous tissue that can be obtained with minimal invasive procedures like colonoscopy or skin punch biopsies has so far yielded inconsistent results, but, if further refined, may open up another window into detecting preclinical PD pathology.

Taken together, current evidence strongly supports a paradigm shift in the diagnosis of PD with a new focus on defining prodromal stages of the disease. In fact, a task force of the International Parkinson and Movement Disorder Society (MDS) has very recently developed research criteria for the definition of prodromal PD by combining various risk and prodromal markers [153] with the ultimate goal of designing clinical trials to test interventions for disease prevention in at-risk individuals.

\section{CONFLICT OF INTEREST}

The authors report no conflict of interest related to this manuscript. 


\section{REFERENCES}

[1] Gibb WR, \& Lees A J (1988) The relevance of the Lewy body to the pathogenesis of idiopathic Parkinson's disease. J Neurol Neurosurg Psychiatry, 51, 745-752.

[2] Greffard S, Verny M, Bonnet A-M, Beinis J-Y, Gallinari C, Meaume S, Piette F, Hauw J-J, \& Duyckaerts C (2006) Motor score of the unified Parkinson disease rating scale as a good predictor of Lewy body-associated neuronal loss in the substantia nigra. Arch Neurol, 63, 584-588.

[3] Fearnley JM, \& Lees AJ (1991) Ageing and Parkinson's disease: Substantia nigra regional selectivity. Brain, 114(Pt 5), 2283-2301.

[4] Braak H, Del Tredici K, Bratzke H, Hamm-Clement J, Sandmann-Keil D, \& Rüb U (2002) Staging of the intracerebral inclusion body pathology associated with idiopathic Parkinson's disease (preclinical and clinical stages). J Neurol, 249 (Suppl), III/1-5.

[5] Del Tredici K, \& Braak H (2012) Lewy pathology and neurodegeneration in premotor Parkinson's disease. Mov Disord, 27, 597-607.

[6] Dickson DW, Fujishiro H, Orr C, DelleDonne A, Josephs KA, Frigerio R, Burnett M, Parisi JE, Klos KJ, \& Ahlskog JE (2009) Neuropathology of non-motor features of Parkinson disease. Parkinsonism Relat Disord, 15, S1-S5.

[7] Pont-Sunyer C, Hotter A, Gaig C, Seppi K, Compta Y, Katzenschlager R, Mas N, Hofeneder D, Brücke T, Bayés A, Wenzel K, Infante J, Zach H, Pirker W, Posada IJ, Álvarez R, Ispierto L, De Fábregues O, Callén A, Palasí A, Aguilar M, Martí MJ, Valldeoriola F, Salamero M, Poewe W, \& Tolosa $\mathrm{E}(2015)$ The onset of nonmotor symptoms in Parkinson's disease (The ONSET PDStudy). Mov Disord, 30, 229-237.

[8] Schrag A, Horsfall L, Walters K, Noyce A, \& Petersen I (2014) Prediagnostic presentations of Parkinson's disease in primary care: A case-control study. Lancet Neurol, 14, 57-64.

[9] Gaenslen A, Swid I, Liepelt-Scarfone I, Godau J, \& Berg D (2011) The patients' perception of prodromal symptoms before the initial diagnosis of Parkinson's disease. Mov Disord, 26, 653-658.

[10] Abbott RD, Petrovitch H, White LR, Masaki KH, Tanner CM, Curb JD, Grandinetti a, Blanchette PL, Popper JS, \& Ross GW(2001) Frequency of bowel movements and the future risk of Parkinson's disease. Neurology, 57, 456-462.

[11] Savica R, Carlin JM, Grossardt BR, Bower JH, Ahlskog JE, Maraganore DM, Bharucha AE, \& Rocca WA (2009) Medical records documentation of constipation preceding Parkinson disease: A case-control study. Neurology, 73, 1752-1758.

[12] Ishihara L, \& Brayne C (2006) A systematic review of depression and mental illness preceding Parkinson's disease. Acta Neurol Scand, 113, 211-220.

[13] Shiba M, Bower JH, Maraganore DM, McDonnell SK, Peterson BJ, Ahlskog JE, Schaid DJ, \& Rocca W a (2000) Anxiety disorders and depressive disorders preceding Parkinson's disease: A case-control study. Mov Disord, 15, 669-677.

[14] Postuma RB, Gagnon J-F, Bertrand J-A, Génier Marchand D, \& Montplaisir JY (2015) Parkinson risk in idiopathic REM sleep behavior disorder: Preparing for neuroprotective trials. Neurology, 84, 1104-1113.

[15] Iranzo A, Tolosa E, Gelpi E, Molinuevo JL, Valldeoriola F, Serradell M, Sanchez-Valle R, Vilaseca I, Lomeña F, Vilas D, LLadó A, Gaig C, \& Santamaria J (2013) Neurodegenerative disease status and post-mortem pathology in idiopathic rapid-eye-movement sleep behaviour disorder: An observational cohort study. Lancet Neurol, 12, 443-453.

[16] Berg D, Godau J, Seppi K, Behnke S, Liepelt-Scarfone I, Lerche S, Stockner H, Gaenslen A, Mahlknecht P, Huber H, Srulijes K, Klenk J, Fassbender K, Maetzler W, \& Poewe W (2013) The PRIPS study: Screening battery for subjects at risk for Parkinson's disease. Eur J Neurol, 20, 102-108.

[17] Ross GW, Petrovitch H, Abbott RD, Tanner CM, Popper J, Masaki K, Launer L, \& White LR (2008) Association of olfactory dysfunction with risk for future Parkinson's disease. Ann Neurol, 63, 167-173.

[18] Stern MB, Lang A, \& Poewe W (2012) Toward a redefinition of Parkinson's disease. Mov Disord, 27, 54-60.

[19] Berg D, Postuma RB, Bloem B, Chan P, Dubois B, Gasser T, Goetz CG, Halliday GM, Hardy J, Lang AE, Litvan I, Marek K, Obeso J, Oertel W, Olanow CW, Poewe W, Stern M, \& Deuschl G (2014) Time to redefine PD? Introductory statement of the MDS Task Force on the definition of Parkinson's disease. Mov Disord, 29, 454-462.

[20] Dickson DW, Braak H, Duda JE, Duyckaerts C, Gasser T, Halliday GM, Hardy J, Leverenz JB, Del Tredici K, Wszolek ZK, \& Litvan I (2009) Neuropathological assessment of Parkinson's disease: Refining the diagnostic criteria. Lancet Neurol, 8, 1150-1157.

[21] Vingerhoets FJ, Schulzer M, Calne DB, \& Snow BJ (1997) Which clinical sign of Parkinson's disease best reflects the nigrostriatal lesion? Ann Neurol, 41, 58-64.

[22] Buchman AS, Shulman JM, Nag S, Leurgans SE, Arnold SE, Morris MC, Schneider JA, \& Bennett DA (2012) Nigral pathology and parkinsonian signs in elders without Parkinson disease. Ann Neurol, 71, 258-266.

[23] Ross GW, Petrovitch H, Abbott RD, Nelson J, Markesbery W, Davis D, Hardman J, Launer L, Masaki K, Tanner CM, \& White LR (2004) Parkinsonian signs and substantia nigra neuron density in decendents elders without PD. Ann Neurol, 56, 532-539.

[24] Dickson DW, Fujishiro H, DelleDonne A, Menke J, Ahmed Z, Klos KJ, Josephs KA, Frigerio R, Burnett M, Parisi JR, \& Ahlskog JE (2008) Evidence that incidental Lewy body disease is pre-symptomatic Parkinson's disease. Acta Neuropathol, 115, 437-444.

[25] Ross GW, Abbott RD, Petrovitch H, Tanner CM, Davis DG, Nelson J, Markesbery WR, Hardman J, Masaki K, Launer L, \& White LR (2006) Association of olfactory dysfunction with incidental Lewy bodies. Mov Disord, 21, 2062-7.

[26] Abbott RD, Ross GW, Petrovitch H, Tanner CM, Davis DG, Masaki KH, Launer LJ, Curb JD, \& White LR (2007) Bowel movement frequency in late-life and incidental Lewy bodies. Mov Disord, 22, 1581-1586.

[27] Kraemmer J, Kovacs GG, Perju-Dumbrava L, Pirker S, Traub-Weidinger T, \& Pirker W (2014) Correlation of striatal dopamine transporter imaging with post mortem substantia nigra cell counts. Mov Disord, 29, 1767-1773.

[28] Marek K, Innis R, van Dyck C, Fussell B, Early M, Eberly S, Oakes D, \& Seibyl J (2001) [123I]beta-CIT SPECT imaging assessment of the rate of Parkinson's disease progression. Neurology, 57, 2089-2094.

[29] Godau J, Hussl A, Lolekha P, Stoessl AJ, \& Seppi K (2012) Neuroimaging: Current role in detecting pre-motor Parkinson's disease. Mov Disord, 27, 634-643.

[30] Morrish PK, Rakshi JS, Bailey DL, Sawle GV, \& Brooks DJ (1998) Measuring the rate of progression and estimating the preclinical period of Parkinson's disease with [18F]dopa PET. J Neurol Neurosurg Psychiatry, 64, 314-319. 
[31] De La Fuente-Fernández R, Schulzer M, Kuramoto L, Cragg J, Ramachandiran N, Au WL, Mak E, McKenzie J, McCormick S, Sossi V, Ruth TJ, Lee CS, Calne DB, \& Stoessl AJ (2011) Age-specific progression of nigrostriatal dysfunction in Parkinson's disease. Ann Neurol, 69, 803-810.

[32] Hilker R, Schweitzer K, Coburger S, Ghaemi M, Weisenbach S, Jacobs AH, Rudolf J, Herholz K, \& Heiss W-D (2005) Nonlinear progression of Parkinson disease as determined by serial positron emission tomographic imaging of striatal fluorodopa F 18 activity. Arch Neurol, 62, 378-382.

[33] Bezard E, Gross CE, \& Brotchie JM (2003) Presymptomatic compensation in Parkinson's disease is not dopaminemediated. Trends Neurosci, 26, 215-221.

[34] Van Nuenen BFL, Van Eimeren T, Van Der Vegt JPM, Buhmann C, Klein C, Bloem BR, \& Siebner HR (2009) Mapping preclinical compensation in Parkinson's disease: An imaging genomics approach. Mov Disord, 24(Suppl 2), S703-S710.

[35] Maetzler W, \& Hausdorff JM (2012) Motor signs in the prodromal phase of Parkinson's disease. Mov Disord, 27, 627-633.

[36] Bennett DA, Beckett LA, Murray AM, Shannon KM, Goetz CG, Pilgrim DM, \& Evans DA (1996) Prevalence of parkinsonian signs and associated mortality in a community population of older people. $N$ Engl J Med, 334, 71-76.

[37] Louis ED, \& Bennett DA (2007) Mild Parkinsonian signs: An overview of an emerging concept. Mov Disord, 22, 16811688.

[38] Postuma RB, Lang AE, Gagnon JF, Pelletier A, \& Montplaisir JY (2012) How does parkinsonism start? Prodromal parkinsonism motor changes in idiopathic REM sleep behaviour disorder. Brain, 135, 1860-1870.

[39] Mirelman A, Gurevich T, Giladi N, Bar-Shira A, Orr-Urtreger A, \& Hausdorff JM (2011) Gait alterations in healthy carriers of the LRRK2 G2019S mutation. Ann Neurol, 69, 193-197.

[40] Maetzler W, Mancini M, Liepelt-Scarfone I, Müller K, Becker C, van Lummel RC, Ainsworth E, Hobert M, Streffer J, Berg D, \& Chiari L (2012) Impaired trunk stability in individuals at high risk for Parkinson's disease. PLoS One, 7, e32240.

[41] Noyce AJ, Bestwick JP, Silveira-Moriyama L, Hawkes CH, Giovannoni G, Lees AJ, \& Schrag A (2012) Meta-analysis of early nonmotor features and risk factors for Parkinson disease. Ann Neurol, 72, 893-901.

[42] Noyce AJ, Bestwick JP, Silveira-Moriyama L, Hawkes CH, Knowles CH, Hardy J, Giovannoni G, Nageshwaran S, Osborne C, Lees AJ, \& Schrag A (2014) PREDICT-PD: Identifying risk of Parkinson's disease in the community: Methods and baseline results. J Neurol Neurosurg Psychiatry, 85, 31-7.

[43] Barone P, Antonini A, Colosimo C, Marconi R, Morgante L, Avarello TP, Bottacchi E, Cannas A, Ceravolo G, Ceravolo R, Cicarelli G, Gaglio RM, Giglia RM, Iemolo F, Manfredi M, Meco G, Nicoletti A, Pederzoli M, Petrone A, Pisani A, Pontieri FE, Quatrale R, Ramat S, Scala R, Volpe G, Zappulla S, Bentivoglio AR, Stocchi F, Trianni G, \& Del Dotto P (2009) The PRIAMO study: A multicenter assessment of nonmotor symptoms and their impact on quality of life in Parkinson's disease. Mov Disord, 24, 1641-1649.

[44] Erro R, Picillo M, Vitale C, Amboni M, Moccia M, Longo K, Cozzolino A, Giordano F, Rosa A De, Michele G De, Pellecchia MT, \& Barone P (2013) Non-motor symptoms in early Parkinson's disease: A 2-year follow-up study on previously untreated patients. J Neurol Neurosurg Psychiatry, 84, 14-17.

[45] Khoo TK, Yarnall AJ, Duncan GW, Coleman S, O'Brien JT, Brooks DJ, Barker RA, \& Burn DJ (2013) The spectrum of nonmotor symptoms in early Parkinson disease. Neurology, 80, 276-281.

[46] Poewe W (2008) Non-motor symptoms in Parkinson's disease. Eur J Neurol, 15, 14-20.

[47] Postuma RB, Aarsland D, Barone P, Burn DJ, Hawkes $\mathrm{CH}$, Oertel W, \& Ziemssen T (2012) Identifying prodromal Parkinson's disease: Pre-Motor disorders in Parkinson's disease. Mov Disord, 27, 617-626.

[48] Braak H, Del Tredici K, Rüb U, De Vos RaI, Jansen Steur ENH, \& Braak E (2003) Staging of brain pathology related to sporadic Parkinson's disease. Neurobiol Aging, 24, 197-211.

[49] Ponsen MM, Stoffers D, Wolters EC, Booij J, \& Berendse HW (2010) Olfactory testing combined with dopamine transporter imaging as a method to detect prodromal Parkinson's disease. J Neurol Neurosurg Psychiatry, 81, 396-399.

[50] Postuma RB, Gagnon J-F, Vendette M, Desjardins C, \& Montplaisir JY (2011) Olfaction and color vision identify impending neurodegeneration in rapid eye movement sleep behavior disorder. Ann Neurol, 69, 811-818.

[51] Ritz B, Lee P, Lassen CF, \& Arah OA (2014) Parkinson disease and smoking revisited: Ease of quitting is an early sign of the disease. Neurology, 83, 1396-1402.

[52] Moccia M, Erro R, Picillo M, Vassallo E, Vitale C, Longo K, Amboni M, Santangelo G, Palladino R, Nardone A, Triassi M, Barone P, \& Pellecchia MT (2015) Quitting smoking: An early non-motor feature of Parkinson's disease? Parkinsonism Relat Disord, 21, 216-220.

[53] Patel AJ, Sarwar AI, Jankovic J, \& Viswanathan A (2014) Bilateral pallidal deep brain stimulation for X-linked dystonia-parkinsonism. World Neurosurg, 82, 241.e1241.e4.

[54] Schenck CH, Boeve BF, \& Mahowald MW (2013) Delayed emergence of a parkinsonian disorder or dementia in $81 \%$ of older men initially diagnosed with idiopathic rapid eye movement sleep behavior disorder: A 16-year update on a previously reported series. Sleep Med, 14, 744-748.

[55] Abbott RD, Ross GW, White LR, Tanner CM, Masaki KH, Nelson JS, Curb JD, \& Petrovitch H (2005) Excessive daytime sleepiness and subsequent development of Parkinson disease. Neurology, 65, 1442-1446.

[56] Doty RL (2012) Olfactory dysfunction in Parkinson disease. Nat Rev Neurol, 8, 329-339.

[57] Haehner A, Boesveldt S, Berendse HW, Mackay-Sim A, Fleischmann J, Silburn PA, Johnston AN, Mellick GD, Herting B, Reichmann H, \& Hummel T (2009) Prevalence of smell loss in Parkinson's disease - A multicenter study. Parkinsonism Relat Disord, 15, 490-494.

[58] Mahlknecht P, Iranzo A, Högl B, Frauscher B, Müller C, Santamaría J, Tolosa E, Serradell M, Mitterling T, Gschliesser V, Goebel G, Brugger F, Scherfler C, Poewe W, Seppi K, Sleep Innsbruck Barcelona Group (2015) Olfactory dysfunction predicts early transition to a Lewy body disease in idiopathic RBD. Neurology, 84, 654-658.

[59] Schenck CH, Bundlie SR, Ettinger MG, \& Mahowald MW (1986) Chronic behavioral disorders of human REM sleep: A new category of parasomnia. Sleep, 9, 293-308.

[60] Gagnon JF, Postuma RB, Mazza S, Doyon J, \& Montplaisir J (2006) Rapid-eye-movement sleep behaviour disorder and neurodegenerative diseases. Lancet Neurol, 5, 424-432. 
[61] Mahlknecht P, Seppi K, Frauscher B, Kiechl S, Willeit J, Stockner H, Djamshidian A, Nocker M, Rastner V, Defrancesco M, Rungger G, Gasperi A, Poewe W, \& Högl B (2015) Probable RBD and association with neurodegenerative disease markers: A population-based study. Mov Disord, 30, 1417-1421.

[62] Postuma RB, Gagnon JF, Vendette M, Fantini ML, Massicotte-Marquez J, \& Montplaisir J (2009) Quantifying the risk of neurodegenerative disease in idiopathic REM sleep behavior disorder. Neurology, 72, 1296-1300.

[63] Postuma RB, Iranzo A, Hogl B, Arnulf I, Ferini-Strambi L, Manni R, Miyamoto T, Oertel W, Dauvilliers Y, Ju Y-E, Puligheddu M, Sonka K, Pelletier A, Santamaria J, Frauscher B, Leu-Semenescu S, Zucconi M, Terzaghi M, Miyamoto M, Unger MM, Carlander B, Fantini M-L, \& Montplaisir JY (2015) Risk factors for neurodegeneration in idiopathic rapid eye movement sleep behavior disorder: A multicenter study. Ann Neurol, 77, 830-839.

[64] Abbott RD, Ross GW, Petrovitch H, Tanner CM, Davis DG, Masaki KH, Launer LJ, Curb JD, \& White LR (2007) Bowel movement frequency in late-life and incidental Lewy bodies. Mov Disord, 22, 1581-1586.

[65] Pouclet H, Lebouvier T, Coron E, Bruley des Varannes S, Rouaud T, Roy M, Neunlist M, \& Derkinderen P (2012) A comparison between rectal and colonic biopsies to detect Lewy pathology in Parkinson's disease. Neurobiol Dis, 45, 305-309.

[66] Shannon KM, Keshavarzian A, Mutlu E, Dodiya HB, Daian D, Jaglin JA, \& Kordower JH (2012) Alpha-synuclein in colonic submucosa in early untreated Parkinson's disease. Mov Disord, 27, 709-715.

[67] Siderowf A, \& Lang AE (2012) Premotor Parkinson's disease: Concepts and definitions. Mov Disord, 27, 608-616.

[68] Definitions B, \& Group W (2001) Biomarkers and surrogate endpoints: Preferred definitions and conceptual framework. Clin Pharmacol Ther, 69, 89-95.

[69] Ponsen MM, Stoffers D, Booij J, Van Eck-Smit BLF, Wolters EC, \& Berendse HW (2004) Idiopathic hyposmia as a preclinical sign of Parkinson's disease. Ann Neurol, 56, 173181.

[70] Iranzo A, Valldeoriola F, Lomeña F, Molinuevo JL, Serradell M, Salamero M, Cot A, Ros D, Pavía J, Santamaria J, \& Tolosa E (2011) Serial dopamine transporter imaging of nigrostriatal function in patients with idiopathic rapid-eyemovement sleep behaviour disorder: A prospective study. Lancet Neurol, 10, 797-805.

[71] Jennings D, Siderowf A, Stern M, Seibyl J, Eberly S, Oakes D, Marek K, PARS Investigators (2014) Imaging prodromal Parkinson disease: The Parkinson Associated Risk Syndrome Study. Neurology, 83, 1739-1746.

[72] Eberling JL, Dave KD, \& Frasier M a (2013) $\alpha$-synuclein imaging: A critical need for Parkinson's disease research. J Parkinsons Dis, 3, 565-567.

[73] Scherfler C, Frauscher B, Schocke M, Iranzo A, Gschliesser V, Seppi K, Santamaria J, Tolosa E, Högl B, \& Poewe W (2011) White and gray matter abnormalities in idiopathic rapid eye movement sleep behavior disorder: A diffusiontensor imaging and voxel-based morphometry study. Ann Neurol, 69, 400-407.

[74] Unger MM, Belke M, Menzler K, Heverhagen JT, Keil B, Stiasny-Kolster K, Rosenow F, Diederich NJ, Mayer G, Möller JC, Oertel WH, \& Knake S (2010) Diffusion tensor imaging in idiopathic REM sleep behavior disorder reveals microstructural changes in the brainstem, substantia nigra, olfactory region, and other brain regions. Sleep, 33, 767-773.

[75] Rolheiser TM, Fulton HG, Good KP, Fisk JD, McKelvey JR, Scherfler C, Khan NM, Leslie RA, \& Robertson HA (2011) Diffusion tensor imaging and olfactory identification testing in early-stage Parkinson's disease. J Neurol, 258, 1254-1260.

[76] Vaillancourt DE, Prodoehl J, Abraham I, Corcos DM, Zhou XJ, Cornelia CL, \& Little DM (2009) High-resolution diffusion tensor imaging in the substantia nigra of de novo Parkinson disease. Neurology, 72, 1378-1384.

[77] Scherfler C, Schocke MF, Seppi K, Esterhammer R, Brenneis C, Jaschke W, Wenning GK, \& Poewe W (2006) Voxel-wise analysis of diffusion weighted imaging reveals disruption of the olfactory tract in Parkinson's disease. Brain, 129, 538-542.

[78] Ibarretxe-Bilbao N, Junque C, Marti MJ, Valldeoriola F, Vendrell P, Bargallo N, Zarei M, \& Tolosa E (2010) Olfactory impairment in Parkinson's disease and white matter abnormalities in central olfactory areas: A voxel-based diffusion tensor imaging study. Mov Disord, 25, 1888-1894.

[79] Blazejewska AI, Schwarz ST, Pitiot A, Stephenson MC, Lowe J, Bajaj N, Bowtell RW, Auer DP, \& Gowland PA (2013) Visualization of nigrosome 1 and its loss in PD: Pathoanatomical correlation and in vivo $7 \mathrm{~T}$ MRI. Neurology, 81, 534-540.

[80] Schwarz ST, Afzal M, Morgan PS, Bajaj N, Gowland PA, \& Auer DP (2014) The "swallow tail" appearance of the healthy nigrosome - a new accurate test of Parkinson's disease: A case-control and retrospective cross-sectional MRI study at 3T. PLoS One, 9, e93814.

[81] Reiter E, Mueller C, Pinter B, Krismer F, Scherfler C, Esterhammer R, Kremser C, Schocke M, Wenning GK, Poewe W, \& Seppi K (2015) Dorsolateral nigral hyperintensity on 3.0T susceptibility-weighted imaging in neurodegenerative Parkinsonism. Mov Disord, 30, 1068-1076.

[82] Berg D, \& Gaenslen A (2010) Place value of transcranial sonography in early diagnosis of Parkinson's disease. Neurodegener Dis, 7, 291-299.

[83] Mahlknecht P, Seppi K, Stockner H, Nocker M, Scherfler C, Kiechl S, Willeit J, Schmidauer C, Gasperi A, Rungger G, \& Poewe W (2013) Substantia nigra hyperechogenicity as a marker for parkinson's disease: A population-based study. Neurodegener Dis, 12, 212-218.

[84] Behnke S, Runkel A, Kassar HAS, Ortmann M, Guidez D, Dillmann U, Fassbender K, \& Spiegel J (2013) Long-term course of substantia nigra hyperechogenicity in Parkinson's disease. Mov Disord, 28, 455-459.

[85] Mahlknecht P, Stockner H, Nocker M, Kiechl S, Willei J, Scherfler C, Sojer M, Gasperi A, Rungger G, Poewe W, \& Seppi K (2012) A follow-up study of substantia nigra echogenicity in healthy adults. Mov Disord, 27, 11961197.

[86] Iranzo A, Stockner H, Serradell M, Seppi K, Valldeoriola F, Frauscher B, Molinuevo JL, Vilaseca I, Mitterling T, Gaig C, Vilas D, Santamaria J, Högl B, Tolosa E, \& Poewe W (2014) Five-year follow-up of substantia nigra echogenicity in idiopathic REM sleep behavior disorder. Mov Disord, 29, 1774-1780.

[87] Berg D, Roggendorf W, Schröder U, Klein R, Tatschner T, Benz P, Tucha O, Preier M, Lange KW, Reiners K, Gerlach M, \& Becker G (2002) Echogenicity of the substantia nigra: Association with increased iron content and marker for susceptibility to nigrostriatal injury. Arch Neurol, 59, 999-1005. 
[88] Berg D, Godau J, Riederer P, Gerlach M, \& Arzberger T (2010) Microglia activation is related to substantia nigra echogenicity. J Neural Transm, 117, 1287-1292.

[89] Berg D, Becker G, Zeiler B, Tucha O, Hofmann E, Preier M, Benz P, Jost W, Reiners K, \& Lange KW (1999) Vulnerability of the nigrostriatal system as detected by transcranial ultrasound. Neurology, 53, 1026-1031.

[90] Behnke S, Schroeder U, Dillmann U, Buchholz HG, Schreckenberger M, Fuss G, Reith W, Berg D, \& Krick CM (2009) Hyperechogenicity of the substantia nigra in healthy controls is related to MRI changes and to neuronal loss as determined by F-Dopa PET. Neuroimage, 47, 1237-1243.

[91] Berg D, Seppi K, Behnke S, Liepelt I, Schweitzer K, Stockner H, Wollenweber F, Gaenslen A, Mahlknecht P, Spiegel J, Godau J, Huber H, Srulijes K, Kiechl S, Bentele M, Gasperi A, Schubert T, Hiry T, Probst M, Schneider V, Klenk J, Sawires M, Willeit J, Maetzler W, Fassbender K, Gasser T, \& Poewe W (2011) Enlarged substantia nigra hyperechogenicity and risk for Parkinson disease: A 37-month 3-center study of 1847 older persons. Arch Neurol, 68, 932-937.

[92] Berg D, Behnke S, Seppi K, Godau J, Lerche S, Mahlknecht P, Liepelt-Scarfone I, Pausch C, Schneider N, Gaenslen A, Brockmann K, Srulijes K, Huber H, Wurster I, Stockner H, Kiechl S, Willeit J, Gasperi A, Fassbender K, Gasser T, \& Poewe W (2013) Enlarged hyperechogenic substantia nigra as a risk marker for Parkinson's disease. Mov Disord, 28, 216-219.

[93] Mahlknecht P, Kiechl S, Stockner H, Willeit J, Gasperi A, Poewe W, \& Seppi K (2015) Predictors for mild parkinsonian signs: A prospective population-based study. Parkinsonism Relat Disord, 21, 321-324.

[94] Sierra M, Sánchez-Juan P, Martínez-Rodríguez MI, González-Aramburu I, García-Gorostiaga I, Quirce MR, Palacio E, Carril JM, Berciano J, Combarros O, \& Infante J (2013) Olfaction and imaging biomarkers in premotor LRRK2 G2019S-associated Parkinson disease. Neurology, 80, 621-626.

[95] Trinh J, \& Farrer M (2013) Advances in the genetics of Parkinson disease. Nat Rev Neurol, 9, 445-454.

[96] Sidransky E, Nalls MA, Aasly JO, Aharon-Peretz J, Annesi G, Barbosa ER, Bar-Shira A, Berg D, Bras J, Brice A, Chen C-M, Clark LN, Condroyer C, De Marco E V, Dürr A Eblan MJ, Fahn S, Farrer MJ, Fung H-C, Gan-Or Z, Gasser T, Gershoni-Baruch R, Giladi N, Griffith a, Gurevich T, Januario C, Kropp P, Lang AE, Lee-Chen G-J, Lesage S, Marder K, Mata IF, Mirelman a, Mitsui J, Mizuta I, Nicoletti G, Oliveira C, Ottman R, Orr-Urtreger A, Pereira L V, Quattrone a, Rogaeva E, Rolfs a, Rosenbaum H, Rozenberg R, Samii a, Samaddar T, Schulte C, Sharma M, Singleton a, Spitz M, Tan E-K, Tayebi N, Toda T, Troiano AR, Tsuji S, Wittstock M, Wolfsberg TG, Wu Y-R, Zabetian CP, Zhao Y, \& Ziegler SG (2009) Multicenter analysis of glucocerebrosidase mutations in Parkinson's disease. $N$ Engl J Med, 361, 1651-1661.

[97] Anheim M, Elbaz A, Lesage S, Durr A, Condroyer C, Viallet F, Pollak P, Bonaïti B, Bonaïti-Pellié C, \& Brice A (2012) Penetrance of Parkinson disease in glucocerebrosidase gene mutation carriers. Neurology, 78, 417-420.

[98] Brockmann K, Srulijes K, Pflederer S, Hauser A-K, Schulte C, Maetzler W, Gasser T, \& Berg D (2015) GBA-associated Parkinson's disease: Reduced survival and more rapid progression in a prospective longitudinal study. Mov Disord, 30, 407-411.

[99] Beavan M, McNeill A, Proukakis C, Hughes DA, Mehta A, \& Schapira AHV (2015) Evolution of prodromal clinical markers of Parkinson disease in a GBA mutation-positive cohort. JAMA Neurol, 72, 201-208.

[100] Mencacci NE, Isaias IU, Reich MM, Ganos C, Plagnol V, Polke JM, Bras J, Hersheson J, Stamelou M, Pittman AM, Noyce AJ, Mok KY, Opladen T, Kunstmann E, Hodecker S, Münchau A, Volkmann J, Samnick S, Sidle K, Nanji T, Sweeney MG, Houlden H, Batla A, Zecchinelli AL, Pezzoli G, Marotta G, Lees A, Alegria P, Krack P, Cormier-Dequaire F, Lesage S, Brice A, Heutink P, Gasser T, Lubbe SJ, Morris HR, Taba P, Koks S, Majounie E, Raphael Gibbs J, Singleton A, Hardy J, Klebe S, Bhatia KP, \& Wood NW (2014) Parkinson's disease in GTP cyclohydrolase 1 mutation carriers. Brain, 137, 2480-2492.

[101] Nalls MA, Plagnol V, Hernandez DG, Sharma M, Sheerin UM, Saad M, Simón-Sánchez J, Schulte C, Lesage S, Sveinbjörnsdóttir S, Stefánsson K, Martinez M, Hardy J, Heutink P, Brice A, Gasser T, Singleton AB, \& Wood NW (2011) Imputation of sequence variants for identification of genetic risks for Parkinson's disease: A meta-analysis of genome-wide association studies. Lancet, 377, 641-649.

[102] Nalls MA, Pankratz N, Lill CM, Do CB, Hernandez DG, Saad M, DeStefano AL, Kara E, Bras J, Sharma M, Schulte C, Keller MF, Arepalli S, Letson C, Edsall C, Stefansson H, Liu X, Pliner H, Lee JH, Cheng R; International Parkinson's Disease Genomics Consortium (IPDGC); Parkinson's Study Group (PSG) Parkinson's Research: The Organized GENetics Initiative (PROGENI); 23 and Me; GenePD; NeuroGenetics Research Consortium (NGRC); Hussman Institute of Human Genomics (HIHG); Ashkenazi Jewish Dataset Investigator; Cohorts for Health and Aging Research in Genetic Epidemiology (CHARGE); North American Brain Expression Consortium (NABEC); United Kingdom Brain Expression Consortium (UKBEC); Greek Parkinson's Disease Consortium; Alzheimer Genetic Analysis Group, Ikram MA, Ioannidis JP, Hadjigeorgiou GM, Bis JC, Martinez M, Perlmutter JS, Goate A, Marder K, Fiske B, Sutherland M, Xiromerisiou G, Myers RH, Clark LN, Stefansson K, Hardy JA, Heutink P, Chen H, Wood NW, Houlden H, Payami H, Brice A, Scott WK, Gasser T, Bertram L, Eriksson N, Foroud T, \& Singleton AB (2014) Large-scale meta-analysis of genome-wide association data identifies six new risk loci for Parkinson's disease. Nat Genet, 46, 989-993.

[103] Lill CM, Roehr JT, McQueen MB, Kavvoura FK, Bagade S, Schjeide BM, Schjeide LM, Meissner E, Zauft U, Allen NC, Liu T, Schilling M, Anderson KJ, Beecham G, Berg D, Biernacka JM, Brice A, DeStefano AL, Do CB, Eriksson N, Factor SA, Farrer MJ, Foroud T, Gasser T, Hamza T, Hardy JA, Heutink P, Hill-Burns EM, Klein C, Latourelle JC, Maraganore DM, Martin ER, Martinez M, Myers RH, Nalls MA, Pankratz N, Payami H, Satake W, Scott WK, Sharma M, Singleton AB, Stefansson K, Toda T, Tung JY, Vance J, Wood NW, Zabetian CP; 23andMe Genetic Epidemiology of Parkinson's Disease Consortium; International Parkinson's Disease Genomics Consortium; Parkinson's Disease GWAS Consortium; Wellcome Trust Case Control Consortium 2), Young P, Tanzi RE, Khoury MJ, Zipp F, Lehrach H, Ioannidis JP, \& Bertram L (2012) Comprehensive research synopsis and systematic meta-analyses in Parkinson's disease genetics: The PDgene database. PLoS Genet, 8, 4-13.

[104] Escott-Price V, Nalls MA, Morris HR, Lubbe S, Brice A, Gasser T, Heutink P, Wood NW, Hardy J, Singleton AB, $\&$ Williams NM (2015) Polygenic risk of Parkinson disease is correlated with disease age at onset. Ann Neurol, 77, 582-591. 
[105] Nalls MA, McLean CY, Rick J, Eberly S, Hutten SJ, Gwinn K, Sutherland M, Martinez M, Heutink P, Williams NM, Hardy J, Gasser T, Brice A, Price TR, Nicolas A, Keller MF, Molony C, Gibbs JR, Chen-Plotkin A, Suh E, Letson C, Fiandaca MS, Mapstone M, Federoff HJ, Noyce AJ, Morris H, Van Deerlin VM, Weintraub D, Zabetian C, Hernandez DG, Lesage S, Mullins M, Conley ED, Northover CA, Frasier M5, Marek K, Day-Williams AG, Stone DJ, Ioannidis JP, Singleton AB; Parkinson's Disease Biomarkers Program and Parkinson's Progression Marker Initiative investigators (2015) Diagnosis of Parkinson's disease on the basis of clinical and genetic classification: A populationbased modelling study. Lancet Neurol, 14, 1002-1009.

[106] Pankratz N, Beecham GW, Destefano AL, Dawson TM, Doheny KF, Factor SA, Hamza TH, Hung AY, Hyman BT, Ivinson AJ, Krainc D, Latourelle JC, Clark LN, Marder K, Martin ER, Mayeux R, Ross OA, Scherzer CR, Simon DK, Tanner C, Vance JM, Wszolek ZK, Zabetian CP, Myers RH, Payami H, Scott WK, \& Foroud T (2012) Meta-analysis of Parkinson's Disease: Identification of a novel locus, RIT2. Ann Neurol, 71, 370-384.

[107] Parnetti L, Castrioto A, Chiasserini D, Persichetti E, Tambasco N, El-Agnaf O, \& Calabresi P (2013) Cerebrospinal fluid biomarkers in Parkinson disease. Nat Rev Neurol, 9 , 131-140.

[108] Del Campo M, Mollenhauer B, Bertolotto A, Engelborghs S, Hampel H, Simonsen AH, Kapaki E, Kruse N, Le Bastard N, Lehmann S, Molinuevo JL, Parnetti L, PerretLiaudet A, Sáez-Valero J, Saka E, Urbani A, Vanmechelen E, Verbeek M, Visser PJ, \& Teunissen C (2012) Recommendations to standardize preanalytical confounding factors in Alzheimer's and Parkinson's disease cerebrospinal fluid biomarkers: An update. Biomark Med, 6, 419-430.

[109] Parkinson Progression Marker, Initiative (2011) The Parkinson Progression Marker Initiative (PPMI). Prog Neurobiol, 95, 629-635.

[110] Kang JH, Irwin DJ, Chen-Plotkin AS, Siderowf A, Caspell C, Coffey CS, Waligórska T, Taylor P, Pan S, Frasier M, Marek K, Kieburtz K, Jennings D, Simuni T, Tanner CM, Singleton A, Toga AW, Chowdhury S, Mollenhauer B, Trojanowski JQ, Shaw LM, Parkinson's Progression Markers, Initiative (2013) Association of cerebrospinal fluid betaamyloid 1-42, T-tau, P-tau181, and alpha-synuclein levels with clinical features of drug-naive patients with early Parkinson disease. JAMA Neurol, 70, 1277-1287.

[111] Gao L, Tang H, Nie K, Wang L, Zhao J, Gan R, Huang J, Zhu R, Feng S, Duan Z, Zhang Y, \& Wang L (2015) Cerebrospinal fluid alpha-synuclein as a biomarker for Parkinson's disease diagnosis: A systematic review and meta-analysis. Int J Neurosci, 125, 645-654.

[112] Zetterberg H, Petzold M, \& Magdalinou N (2014) Cerebrospinal fluid $\alpha$-synuclein levels in Parkinson's disease-changed or unchanged? Eur. J Neurol, 21, 365-367.

[113] Shi M, Zabetian CP, Hancock AM, Ginghina C, Hong Z, Yearout D, Chung KA, Quinn JF, Peskind ER, Galasko D, Jankovic J, Leverenz JB, \& Zhang J (2010) Significance and confounders of peripheral DJ-1 and alpha-synuclein in Parkinson's disease. Neurosci Lett, 480, 78-82.

[114] Qiang JK, Wong YC, Siderowf A, Hurtig HI, Xie SX, Lee VMY, Trojanowski JQ, Yearout D, B. Leverenz J, Montine TJ, Stern M, Mendick S, Jennings D, Zabetian C, Marek K, \& Chen-Plotkin AS (2013) Plasma apolipoprotein A1 as a biomarker for Parkinson disease. Ann Neurol, 74, 119-127.
[115] Swanson CR, Berlyand Y, Xie SX, Alcalay RN, Chahine LM, \& Chen-Plotkin AS (2015) Plasma apolipoprotein A1 associates with age at onset and motor severity in early Parkinson's disease patients. Mov Disord, doi: 10.1002/mds. 26290

[116] Lee Y, Lin C, Wu R-M, Lin M-S, Lin J-W, Chang C-H, \& Lai M-S (2013) Discontinuation of statin therapy associates with Parkinson disease: A population-based study. Neurology, 81, 410-416.

[117] Huang X, Alonso A, Guo X, Umbach DM, Lichtenstein ML, Ballantyne CM, Mailman RB, Mosley TH, \& Chen H (2015) Statins, plasma cholesterol, and risk of Parkinson's disease: A prospective study. Mov Disord, 30, 552-559.

[118] Hu G, Antikainen R, Jousilahti P, Kivipelto M, \& Tuomilehto J (2008) Total cholesterol and the risk of Parkinson disease. Neurology, 70, 1972-1979.

[119] Huang X, Abbott RD, Petrovitch H, Mailman RB, \& Ross GW (2008) Low LDL cholesterol and increased risk of Parkinson's disease: Prospective results from Honolulu-Asia Aging Study. Mov Disord, 23, 10131018.

[120] Serafin A, Foco L, Zanigni S, Blankenburg H, Picard A, Zanon A, Giannini G, Pichler I, Facheris MF, Cortelli P, Pramstaller PP, Hicks AA, Domingues FS, \& Schwienbacher C (2015) Overexpression of blood microRNAs 103a, 30b, and 29a in L-dopa-treated patients with PD. Neurology, 84, 645-653.

[121] Khoo SK, Petillo D, Kang UJ, Resau JH, Berryhill B, Linder J, Forsgren L, Neuman LA, \& Tan AC (2012) Plasma-based circulating MicroRNA biomarkers for Parkinson's disease. J Parkinsons Dis, 2, 321-331.

[122] McKhann GM (2011) Changing concepts of Alzheimer disease. JAMA, 305, 2458-2459.

[123] Mollenhauer B, \& Zhang J (2012) Biochemical premotor biomarkers for Parkinson's disease. Mov Disord, 27, 644650.

[124] Hong Z, Shi M, Chung KA, Quinn JF, Peskind ER, Galasko D, Jankovic J, Zabetian CP, Leverenz JB, Baird G, Montine TJ, Hancock AM, Hwang H, Pan C, Bradner J, Kang UJ, Jensen PH, \& Zhang J (2010) DJ-1 and alphasynuclein in human cerebrospinal fluid as biomarkers of Parkinson's disease. Brain, 133, 713-726.

[125] Shi M, Bradner J, Hancock AM, Chung KA, Quinn JF, Peskind ER, Galasko D, Jankovic J, Zabetian CP, Kim HM, Leverenz JB, Montine TJ, Ginghina C, Kang UJ, Cain KC, Wang Y, Aasly J, Goldstein D, \& Zhang J (2011) Cerebrospinal fluid biomarkers for Parkinson disease diagnosis and progression. Ann Neurol, 69, 570-580.

[126] Mollenhauer B, Locascio JJ, Schulz-Schaeffer W, SixelDöring F, Trenkwalder C, \& Schlossmacher MG (2011) $\alpha$-Synuclein and tau concentrations in cerebrospinal fluid of patients presenting with parkinsonism: A cohort study. Lancet Neurol, 10, 230-240.

[127] Van Dijk KD, Bidinosti M, Weiss A, Raijmakers P, Berendse HW, \& van de Berg WDJ (2014) Reduced $\alpha$-synuclein levels in cerebrospinal fluid in Parkinson's disease are unrelated to clinical and imaging measures of disease severity. Eur $J$ Neurol, 21, 388-394.

[128] Mollenhauer B, Trautmann E, Taylor P, Manninger P, SixelDöring F, Ebentheuer J, Trenkwalder C, \& Schlossmacher MG (2013) Total CSF $\alpha$-synuclein is lower in de novo Parkinson patients than in healthy subjects. Neurosci Lett, 532, 44-48. 
[129] Wang Y, Shi M, Chung KA, Zabetian CP, Leverenz JB, Berg D, Srulijes K, Trojanowski JQ, Lee VM-Y, Siderowf AD, Hurtig H, Litvan I, Schiess MC, Peskind ER, Masuda M, Hasegawa M, Lin X, Pan C, Galasko D, Goldstein DS, Jensen PH, Yang H, Cain KC, \& Zhang J (2012) Phosphorylated alpha-synuclein in Parkinson's disease. Sci Transl Med, 4, 121ra20-121ra20.

[130] Tokuda T, Qureshi MM, Ardah MT, Varghese S, Shehab SA, Kasai T, Ishigami N, Tamaoka a, Nakagawa M, \& ElAgnaf OM (2010) Detection of elevated levels of alphasynuclein oligomers in CSF from patients with Parkinson disease. Neurology, 75, 1766-1772.

[131] Wang N, Gibbons CH, Lafo J, \& Freeman BSR (2013) $\alpha$-Synuclein in cutaneous autonomic nerves. Neurology, 81, 1604-1610.

[132] Doppler K, Ebert S, Üçeyler N, Trenkwalder C, Ebentheuer J, Volkmann J, \& Sommer C (2014) Cutaneous neuropathy in Parkinson's disease: A window into brain pathology. Acta Neuropathol, 128, 99-109.

[133] Donadio V, Incensi A, Leta V, Giannoccaro MP, Scaglione C, Martinelli P, Capellari S, Avoni P, Baruzzi A, \& Liguori R (2014) Skin nerve a-synuclein deposits A biomarker for idiopathic Parkinson disease. Neurology, 82, 1362-1369.

[134] Adler CH, Dugger BN, Hinni ML, Lott DG, DriverDunckley E, Hidalgo J, Henry-Watson J, Serrano G, Sue LI, Nagel T, Duffy A, Shill HA, Akiyama H, Walker DG, \& Beach TG (2014) Submandibular gland needle biopsy for the diagnosis of Parkinson disease. Neurology, 82, 858-864.

[135] Devic I, Hwang H, Edgar JS, Izutsu K, Presland R, Pan C, Goodlett DR, Wang Y, Armaly J, Tumas V, Zabetian CP, Leverenz JB, Shi M, \& Zhang J (2011) Salivary alphasynuclein and DJ-1: Potential biomarkers for Parkinson's disease. Brain, 134 (Pt 7), e178.

[136] Schneider SA, Boettner M, Alexoudi A, Zorenkov D, Deuschl G, Wedel T. (2015) Can we use peripheral tissue biopsies to diagnose Parkinson's disease? A review of the literature. Eur J Neurol, doi: 10.1111/ene.12753

[137] Lebouvier T, Neunlist M, des Varannes SB, Coron E, Drouard A, N'Guyen JM, Chaumette T, Tasselli M, Paillusson S, Flamand M, Galmiche JP, Damier P, \& Derkinderen P (2010) Colonic biopsies to assess the neuropathology of Parkinson's disease and its relationship with symptoms. PLoS One, 5, 1-9.

[138] Pouclet H, Lebouvier T, Coron E, Des Varannes SB, Neunlist M, \& Derkinderen P (2012) A comparison between colonic submucosa and mucosa to detect Lewy pathology in Parkinson's disease. Neurogastroenterol Motil, 24, 202-205.

[139] Visanji NP, Marras C, Kern DS, Al Dakheel A, Gao A, Liu LWC, Lang AE, \& Hazrati L-N (2015) Colonic mucosal a-synuclein lacks specificity as a biomarker for Parkinson disease. Neurology, 84, 609-616.

[140] Sprenger F, Gelpi E, Navarro-Otano J, Offner F, Vilas D, Valladeoriola F, Pont-Sunyer C, Aldecoa I, Gaig C, Gines A, Cuatrecases M, Hogl B, Frauscher B, Iranzo A, Wenning GK, Vogel W, Tolosa E, \& Poewe W (2015) Enteric nervous system alpha-synuclein immunoreactivity in idopathic REM sleep behavior disorder. Neurology, Oct 16. pii:10.1212/WNL.0000000000002126. [Epub ahead of print]

[141] Sánchez-Ferro Á, Rábano A, Catalán MJ, RodríguezValcárcel FC, Fernández Díez S, Herreros-Rodríguez J, García-Cobos E, Álvarez-Santullano MM, López-
Manzanares L, Mosqueira AJ, Vela Desojo L, LópezLozano JJ, López-Valdés E, Sánchez-Sánchez R, \& Molina-Arjona JA (2015) In vivo gastric detection of $\alpha$ synuclein inclusions in Parkinson's disease. Mov Disord, 30, 517-524.

[142] Hilton D, Stephens M, Kirk L, Edwards P, Potter R, Zajicek J, Broughton E, Hagan H, \& Carroll C (2014) Accumulation of $\alpha$-synuclein in the bowel of patients in the pre-clinical phase of Parkinson's disease. Acta Neuropathol, 127, 235241.

[143] Shannon KM, Keshavarzian A, Dodiya HB, Jakate S, \& Kordower JH (2012) Is alpha-synuclein in the colon a biomarker for premotor Parkinson's Disease? Evidence from 3 cases. Mov Disord, 27, 716-719.

[144] Böttner M, Zorenkov D, Hellwig I, Barrenschee M, Harde J, Fricke T, Deuschl G, Egberts J-H, Becker T, FritscherRavens A, Arlt A, \& Wedel T (2012) Expression pattern and localization of alpha-synuclein in the human enteric nervous system. Neurobiol Dis, 48, 474-480.

[145] Folgoas E, Lebouvier T, Leclair-Visonneau L, Cersosimo M-G, Barthelaix A, Derkinderen P, \& Letournel F (2013) Diagnostic value of minor salivary glands biopsy for the detection of Lewy pathology. Neurosci Lett, 551, 62-64.

[146] Beach TG, White CL, Hladik CL, Sabbagh MN, Connor DJ, Shill HA, Sue LI, Sasse J, Bachalakuri J, Henry-Watson J, Akiyama H, \& Adler CH (2009) Olfactory bulb alphasynucleinopathy has high specificity and sensitivity for Lewy body disorders. Acta Neuropathol, 117, 169-174.

[147] Witt M, Bormann K, Gudziol V, Pehlke K, Barth K, Minovi A, Hähner A, Reichmann H, \& Hummel T (2009) Biopsies of olfactory epithelium in patients with Parkinson's disease. Mov Disord, 24, 906-914.

[148] Scheperjans F, Aho V, Pereira P AB, Koskinen K, Paulin L, Pekkonen E, Haapaniemi E, Kaakkola S, Eerola-Rautio J, Pohja M, Kinnunen E, Murros K, \& Auvinen P (2015) Gut microbiota are related to Parkinson's disease and clinical phenotype. Mov Disord, 30, 350-358.

[149] Keshavarzian A, Green SJ, Engen P a, Voigt RM, Naqib A, Forsyth CB, Mutlu E, \& Shannon KM (2015) Colonic bacterial composition in Parkinson's disease. Mov Disord, 30, 1351-1360.

[150] Scheperjans F, Pekkonen E, Kaakkola S, \& Auvinen P (2015) Linking smoking, coffee, urate, and Parkinson's disease - a role for gut microbiota? J Parkinsons Dis, 5, 255-262.

[151] Angot E, Steiner JA, Hansen C, Li JY, \& Brundin P (2010) Are synucleinopathies prion-like disorders? Lancet Neurol, 9, 1128-1138.

[152] Woerman AL, Stöhr J, Aoyagi A, Rampersaud R, Krejciova Z, Watts JC, Ohyama T, Patel S, Widjaja K, Oehler A, Sanders DW, Diamond MI, Seeley WW, Middleton LT, Gentleman SM, Mordes DA, Südhof TC, Giles K, \& Prusiner SB(2015) Propagation of prions causing synucleinopathies in cultured cells. Proc Natl Acad Sci U S A, 112, E4949-4958.

[153] Berg D, Postuma RB, Adler CH, Bloem BR, Chan P, Dubois B, Gasser T, Goetz CG, Halliday G, Joseph L, Lang AE, Liepelt-Scarfone I, Litvan I, Marek K, Obeso J, Oertel W, Olanow CW, Poewe W, Stern M, \& Deuschl G (2015) MDS research criteria for prodromal Parkinson's disease. Mov Disord, 30, 1600-1611. 